Publisher homepage: www.universepg.com, ISSN: 2663-7804 (Online) \& 2663-7790 (Print)

https://doi.org/10.34104/ajeit.019.014020

Australian Journal of Engineering and Innovative Technology

Journal homepage: www.universepg.com/journal/ajeit

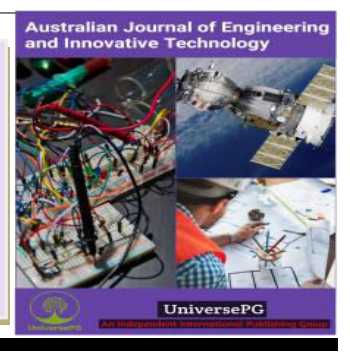

\title{
Assessment on Climate Change Adaptation: A Study on Coastal Area of Khulna District in Bangladesh
}

\author{
Md. Anwarul Islam ${ }^{1}$, Md. Shamsuzzoha ${ }^{2}$, Md. Rasheduzzaman', Rajan Chandra Ghosh' ${ }^{2}$ and Md. Faisal ${ }^{3}$ \\ ${ }^{1}$ Faculty of Disaster Management, Patuakhali Science and Technology University, Dumki, Patuakhali-8602, Bangladesh; \\ ${ }^{2}$ Department of Emergency Management, Patuakhali Science and Technology University, Dumki, Patuakhali-8602, \\ Bangladesh; ${ }^{3}$ Department of Disaster Resilience and Engineering, Patuakhali Science and Technology University, Dumki, \\ Patuakhali-8602, Bangladesh. \\ *Correspondence: islam1973505@stud.kuet.ac.bd
}

\begin{abstract}
Bangladesh is likely to be one of the most vulnerable countries in the world to climate change due to geographical location and geo-morphological conditions. Bangladesh experiences extremely disastrous situation like cyclone, flood, saline water intrusion, water logging, heavy rainfall, river erosion, storm surge etc. that occur frequently in the coastal part of Bangladesh. This results huge loss of lives, damages properties and degrade the integrity of the environmental components. This study was conducted on 2 villages (Chotta Chalna and Shivnagar) of Dacope Upazila of Khulna district with the purpose of assessing existing climate change adaptation scenario and techniques for mitigating climatic change related risks. Necessary data were collected from various sources namely direct household survey, focus group discussion, and key informants interview and from various journals, related thesis papers. About $46 \%$ of the respondents cited cyclone is the most terrific type hazard and $17.33 \%$ respondent cited salinity intrusion is the second devastating type hazard that they faced. The results show that the study area climate change risks are very high and existing climate change adaptation techniques are not effective enough to mitigate the risks. Sustainable climate change adaptation strategies are much needed to mitigate the climate change risks of the study area.
\end{abstract}

Keywords: Climate change, Adaptation, Coastal area, Khulna district, Assessment, and Vulnerable countries.

\section{INTRODUCTION}

Bangladesh is extremely vulnerable to climate change because of its geophysical settings. This low level of development combined with other factors such as its geography and climate, makes the country quite vulnerable to climate change (World Bank, 2002). The country has faced devastating Sidr in November 2007, Aila in April 2009, series of flood of 2004, 2007 and 2009, Nargis in 2010 and Mahasen in May 2013 (Ahmed, 2010). According to Intergovernmental Panel on Climate Change (IPCC, 2001), coastal area of Bangladesh may go under saline water by 2050. Due to the rise in temperature, crop production will be reduced by about $30 \%$. Climate change would decrease the yield of "boro" rice by 55-62\% and wheat by $61 \%$ by 2050 in Bangladesh (Adger, 2003). Agricultural land use in low land areas is very poor, which is roughly 50\% of the country's average (Petersen and Shireen, 2001). Climate change now occupies the top of the environmental concerns that 
impede progress in socioeconomic development and threaten human security. According to $4^{\text {th }}$ IPCC Report, Bangladesh is recognized worldwide as one of the country's most vulnerable to the impacts of global warming and climate change (IPCC, 2007). One critical variable that determines the vulnerability of Bangladesh to climate change impacts is the magnitude of sea level rise. Scientists of Bangladesh believe that because of sea level rise coastal Bangladesh has already experienced the worst impacts especially in terms of coastal inundation and erosion, saline intrusion, deforestation, loss of bio-diversity and agriculture, and large-scale migration (DOE, 2007).

With this background, this study discussed the assessment on climate change adaptation practices in a coastal part of Bangladesh. The biophysical and socioeconomic condition of Dacope upazila in Khulna District is extremely vulnerable and almost every year this region is being affected by natural disasters and climatic stress like cyclone, flood, water logging, salinity intrusion, storm surge, river bank erosion etc. Community peoples of this area loss their lives and livelihoods due to cyclone within a regular interval of time (Author Field Survey, 2018).

Salinity intrusion causes fresh water scarcity in the study area, so the community people largely depended on rain water, GOs and NGOs supply water scheme for drinking purpose. Maximum people of the study area are poor and they do not have adequate knowledge about climate change issues and its impact on their livelihood. They don't know how they can adapt with climate change issues to mitigate climatic risks and how to make their livelihood more secure and resistant to disaster. There is lack of sufficient disaster preparedness at family and community level (Hossain et al., 2019). Considering the above circumstances this study goes with the aim of exploring present climate change adaptation scenario in the study area.

\section{Conceptual framework for process of adaptation to climate change:}

Since climate change was recognized as a problem in the late 1980s, the major focus has been on mitigation (i.e., reducing atmospheric greenhouse-gas emissions) rather than adaptation. However, interest in adaptation to climate change is growing as it is increasingly recognized that some climate change has become inevitable even with significant mitigation. Further, there can be important synergies between adaptation and management of existing problems (Parry et al., 1998).

In an integrated coastal policy that aims to address climate and non-climate issues, the potential for conflict between development objectives and adaptation needs should be minimized. In order to do so, it is important that all stakeholders-governments, universities and government-sponsored laboratories, the private sector, non-governmental organizations and local communities- are aware of the need to reduce coastal vulnerability to climate. In addition, successful coastal management requires that the planning, design and implementation of adaptation technologies be based on the best available information as well as on the regular monitoring and evaluation of their performance. According to Klein et al. (1999) coastal adaptation to climate change can be considered as a multi-stage and iterative process.

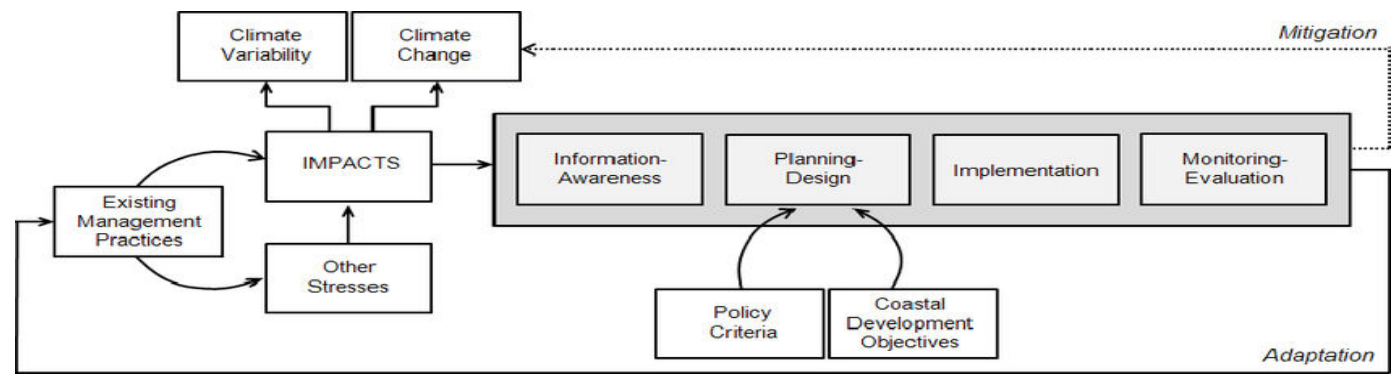

Fig 1: Conceptual framework for coastal adaptation to climate change (Klein et al., 1999). 


\section{METHODOLOGY}

Selection of the study area - Dacope Upazila of Khulna district was selected as the study area to map out the assessment on climate change adaptation practices in order to mitigating climatic risks. The study was performed in Chalna and Kamarkhola Union. Dacope upazila is adjacent with the Sundarban mangrove forest of Khulna district (Bagchi et al., 2019). It is bounded by Pasur River on the south, Batiaghata upazila on the north, Mongla and Rampal Upazila of Bagerhat district on the east, Koyra and Paikgachha Upazila of Satkhira district on the west.

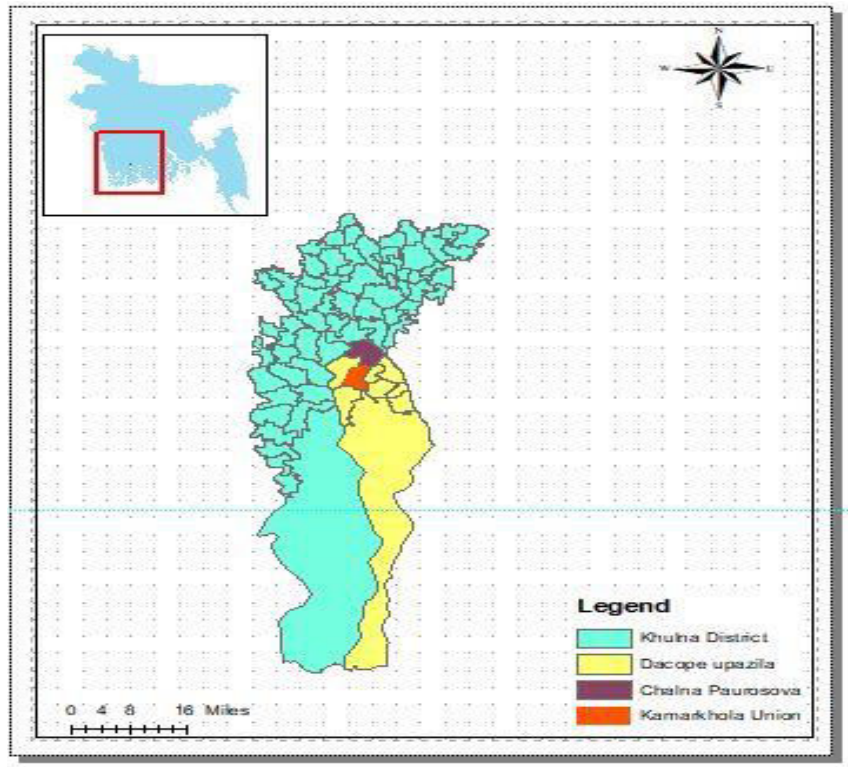

Table 1: Selected Study Areas

\begin{tabular}{|l|c|c|c|}
\hline District & Upazila & Union & Village \\
\hline \multirow{2}{*}{ Khulna } & \multirow{2}{*}{ Dacope } & Chalna & Chotta Chalna \\
\cline { 3 - 4 } & & Kamarkhola & Shivnagar \\
\hline
\end{tabular}

Factors considered for study area selection Following factors were considered for the selection of the study area:

- Higher degree of risk due to climate change related hazard like cyclone, salinity intrusion, river erosion, tidal surge and coastal inundation, etc.

- Availability of adaptation program or project to combat against climate change both by GOs and NGOs.

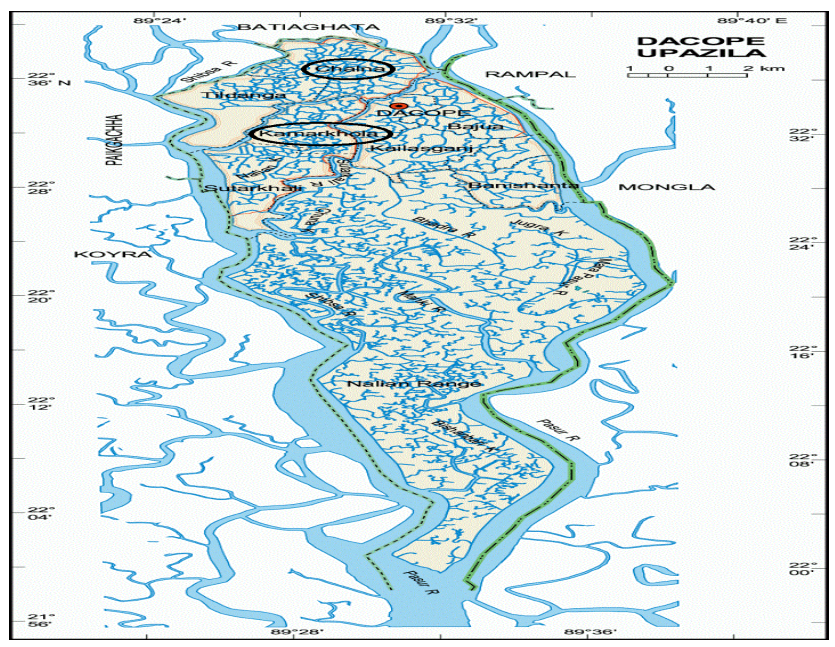

Fig 2: Location of the selected study area map of Khulna district.

Data Collection - In this study, data was collected from both primary and secondary sources. The primary data was collected from direct household survey, focus group discussion and key informant interview and secondary data was collected from various related thesis papers and published journals.

Sample Collection- Sample size calculation (household survey): Yamane's formula:

$\mathrm{n}=\frac{N}{1+N *(e)^{2}}$.......

Where,

$\mathrm{n}=$ Sample size, $\mathrm{N}=$ Population size, and $\mathrm{e}=$ Level of precision or sampling of error.
For the study area (Chotta Chalna)

According to the formula (1), sampling size:

$$
\begin{aligned}
n & =\frac{89}{1+89 *(.05)^{2}} \\
& =72 \sim 70
\end{aligned}
$$

\section{For the study area (Shivnagar)}

According to the formula (1), sampling size:

$$
\begin{aligned}
n & =\frac{104}{1+104 *(.05)^{2}} \\
& =82 \sim 80
\end{aligned}
$$

The study was conducted through total $150(70+80)$ a household survey in the study area. Here, Table 2 shows the sample selection status. 
Table 2: Sample Selection Status of the study area.

\begin{tabular}{|c|c|c|c|}
\hline Village & $\begin{array}{c}\text { Respondents } \\
\text { Number }\end{array}$ & $\begin{array}{c}\text { Respondents } \\
\text { Percentage }\end{array}$ & $\begin{array}{c}\text { Total } \\
\text { Responders }\end{array}$ \\
\hline $\begin{array}{c}\text { Chotta } \\
\text { Chalna }\end{array}$ & 70 & $81 \%$ & 150 \\
\hline Shivnagar & 80 & $76 \%$ & \\
\hline
\end{tabular}

(Author Field Survey, 2018)

\section{Data entry, data processing and map preparation -}

After data collection, data entry and data processing operation were took place. Microsoft Excel software was used for data processing. Study area map was prepared through ArcGIS software.

Results and Discussion - This section describes the output and findings of the study and reveals elaborately the problems regarding successful implementation of adaptation measures to reduce climate change impacts in Dacope Upazila has been investigated and determined.

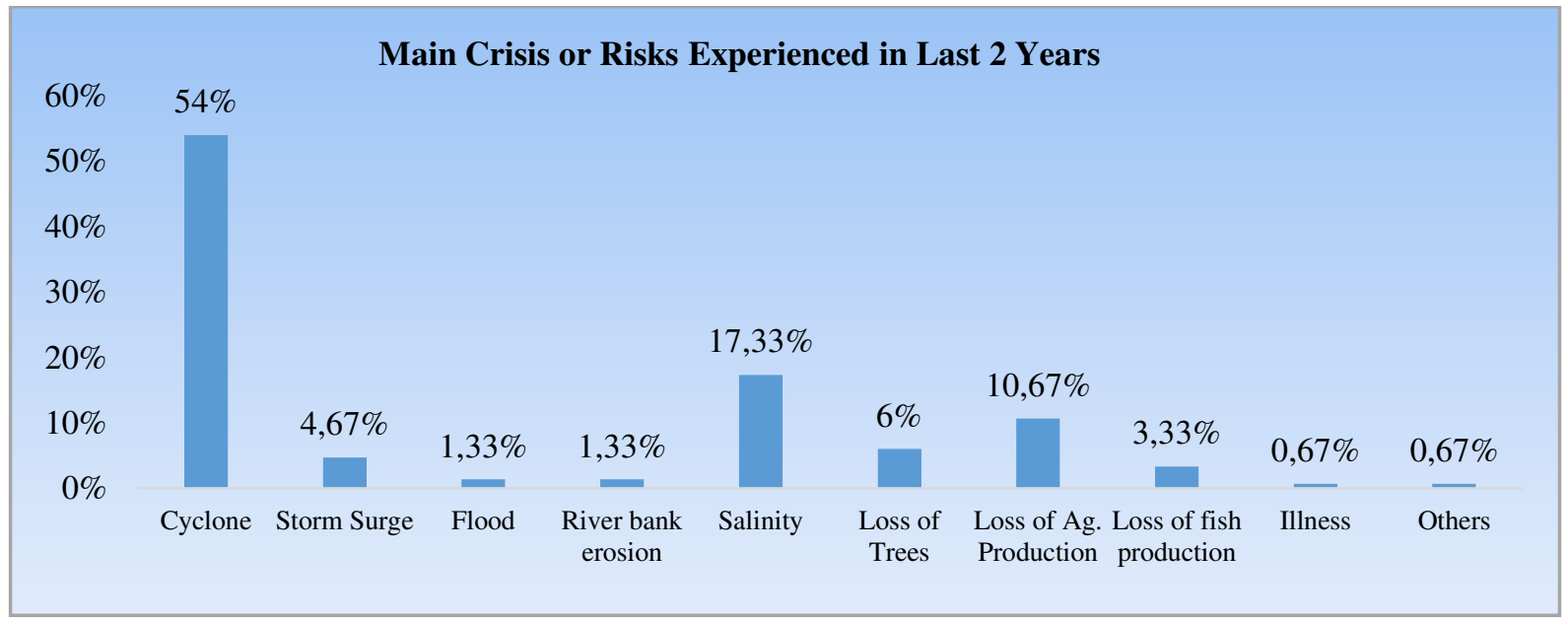

Fig 3: Main crisis experienced by the respondent in 2015-2017 (Author Field Survey, 2018).

Main crisis or risks occurred at present time - The study area is highly vulnerable for Climate change impacts and climatic stress. Different type of hazards occurred in the study area such as cyclone, storm surge, flood, river bank erosion, salinity intrusion and erratic rainfall, unavailability of irrigation water, excess temperature and water logging. Highest $54 \%$ of the respondent cited that cyclone is the most terrific type hazard that the respondent experienced and $17.33 \%$ respondent opined that salinity intrusion is the second devastating type hazard that they faced. Here Fig 3 presented the risk experienced by the respondent in the last 2 year (2015-2017) due to climatic hazards.

\section{MAJOR FINDINGS}

Climate change induced risks and vulnerability were assessed of the study area based on exposure and climate change impacts on socio economic sectors of the respondents. After analysis of physical exposure and socio-economic implications, it was found that housing, production activity, food security, availability of drinking water and change of occupation are major social vulnerable sector of the study area. The study area is economically vulnerable due to the poor production in agriculture, fisheries and livestock sector. The study revealed that the respondent have good indigenous knowledgeable about local environmental conditions.

Respondents generally talk about climate change as changes in the local environment and it causes subsequent problems with their living standards. The respondents are so excruciatingly poor and they don't think about the future. The study found that agricultural adjustments and measures which have already been taken are not adequate. No adaptation measures on climate-sensitive diseases are found in the study areas. Safe drinking water from tube well is not available in Chotta Chalna and Shivnagar. Safe water supply in the study area is not adequate. 
Table 3: Adaptation scenario of the study area.

\begin{tabular}{|c|c|c|c|}
\hline $\begin{array}{l}\text { Problem } \\
\text { area }\end{array}$ & $\begin{array}{c}\text { Adaptation measures practiced in } \\
\text { study areas }\end{array}$ & $\begin{array}{l}\text { Practicing/ } \\
\text { Implementing } \\
\text { authority }\end{array}$ & Comment \\
\hline \multirow[t]{6}{*}{$\begin{array}{l}\text { Drinking } \\
\text { water }\end{array}$} & Use of water purification tablet and Fitkiri & $\begin{array}{l}\text { Indigenous practice, } \\
\text { GO, NGO }\end{array}$ & \multirow{6}{*}{$\begin{array}{l}\text { NGO's are doing well. } \\
\text { GO initiatives are } \\
\text { negligible to meet the local } \\
\text { demand. }\end{array}$} \\
\hline & $\begin{array}{l}\text { Pond excavation and boundary raising for } \\
\text { sweet water preservation }\end{array}$ & $\begin{array}{l}\text { Indigenous practice, } \\
\text { NGO, CBO }\end{array}$ & \\
\hline & Rain water harvesting & NGO & \\
\hline & $\begin{array}{c}\text { Fetch water from long distance and boil } \\
\text { water }\end{array}$ & Indigenous practice & \\
\hline & Distribution of tube well free of cost & GO, NGO & \\
\hline & $\begin{array}{l}\text { Distribution of safe drinking water by } \\
\text { water filtering plant }\end{array}$ & GO, NGO & \\
\hline \multirow[t]{5}{*}{ Agriculture } & Boro cultivation & GO, NGO & \multirow{5}{*}{$\begin{array}{c}\text { GO initiative is negligible } \\
\text { but NGO initiatives are } \\
\text { well }\end{array}$} \\
\hline & Late varieties of Aman are sown & GO, NGO & \\
\hline & $\begin{array}{l}\text { Training, seed collection and technical } \\
\text { Support }\end{array}$ & GO, NGO, CBO & \\
\hline & Early crop harvesting & Indigenous practice & \\
\hline & $\begin{array}{l}\text { Crop land is used to cultivate winter crops } \\
\text { (Rabi crop) }\end{array}$ & $\begin{array}{l}\text { Indigenous practice, } \\
\text { GO, NGO }\end{array}$ & \\
\hline \multirow{5}{*}{$\begin{array}{l}\text { Fisheries } \\
\text { and } \\
\text { Livestock }\end{array}$} & Promote fisheries aquaculture & $\begin{array}{l}\text { Indigenous practice, } \\
\qquad \mathrm{NGO}, \mathrm{CBO}\end{array}$ & \multirow{5}{*}{$\begin{array}{l}\text { Local people } \\
\text { and NGO and } \\
\text { CBO initiative } \\
\text { is good but } \\
\text { GO initiative } \\
\text { is negligible }\end{array}$} \\
\hline & Promotion of salt tolerant species & GO, NGO & \\
\hline & $\begin{array}{l}\text { Rehabilitation of degraded habitat and } \\
\text { maintenance of fish migratory routes }\end{array}$ & GO, NGO & \\
\hline & $\begin{array}{l}\text { Skill enhancement of fisherman } \\
\text { community and create market linkages for } \\
\text { marketing of fish and fisheries product }\end{array}$ & GO, NGO, CBO & \\
\hline & Raising the boundary of pond & Indigenous practice & \\
\hline $\begin{array}{l}\text { Physical } \\
\text { exposure }\end{array}$ & $\begin{array}{l}\text { Embankment } \\
\text { Dredging of river and cannels } \\
\text { Mangrove and non-mangrove forest }\end{array}$ & $\begin{array}{l}\mathrm{GO}, \mathrm{NGO}, \mathrm{CBO} \text {, } \\
\text { Indigenous practice }\end{array}$ & $\begin{array}{l}\text { All these } \mathrm{GO}, \mathrm{NGO}, \mathrm{CBO} \\
\text { and local measures taken to } \\
\text { reduce physical exposure }\end{array}$ \\
\hline \multirow[t]{2}{*}{ Housing } & $\begin{array}{l}\text { Flood resistant housing using new } \\
\text { material and technology }\end{array}$ & $\mathrm{GO}, \mathrm{NGO}$ and $\mathrm{CBO}$ & \multirow[t]{2}{*}{$\begin{array}{c}\text { People, GO, } \\
\text { NGO are involved }\end{array}$} \\
\hline & Housing project for landless people & GO, NGO & \\
\hline \multirow{2}{*}{$\begin{array}{l}\text { Change of } \\
\text { occupation }\end{array}$} & Preparation of "Shutki (dry fish)" & Indigenous practice & \multirow{2}{*}{$\begin{array}{l}\text { GO and different NGO's } \\
\text { roles in "Shutki" } \\
\text { production and marketing }\end{array}$} \\
\hline & $\begin{array}{l}\text { Engage as day labor in crop field, house } \\
\text { building and road construction, mud } \\
\text { cutting, etc. }\end{array}$ & GO, NGO & \\
\hline
\end{tabular}


The study found some currently practiced adaptation measures to climate change that related to practices of indigenous knowledge and GOs, NGOs, CBOs adaptation measures but it is not sufficient for the locality if compared to local people's needs and IPCC proposed list of adaptation measures due to climate change. Adaptation measures is much essentially for the solutions of climatic problems and therefore means addressing basic and immediate needs of water, food security and livelihood strategies. At the same time, it is important to reduce the risk of natural disasters that disrupt the respondent's livelihoods, mobility and damage their homes and assets.

\section{Adaptation techniques for mitigating climate} change risks - The study reveal that the awareness and preparedness of local community towards climate change and its response are increasing by the change of time. At the present time the community people of this study area are involving with different government and non-government organizations climate change adaptation activities. Here, Table 3 presented the adaptation scenario of the study area.

\section{CONCLUSION AND RECOMMENDATION:}

From a country-coverage perspective, the study area (2 villages) might not be a good representative sample. However, issues discussed in the study climate change adaptation and related measure such as the importance of local knowledge, reasons of weakness of different adaptation measures, GO-NGO and local people's coordination scenarios are more or less similar to other districts and villages in Coastal zones of Bangladesh and may also resemble issues in other developing countries. The experiences and lessons learned will have relevance to practitioners and researchers interested in climate change adaptation programs. As the communities are experiencing the success or failure of the aforementioned programs, perception of climate affected communities shall be very helpful in reassessment of existing adaptation measures.

From the above-mentioned discussed of the study area demonstrates following recommendations that make the communities' resilient and less vulnerable to climate change problem: (i)

Strengthening GOs (both national and local), NGOs with local and scientific knowledge, skills and resources, facilitate community-based adaptation, empower people to demand their rights and build their capacity for collective action. International donors should step up and support the program;

(ii) Local adjustment of agricultural system with changing climate through change of planting time of crops, introduction of saline resilient varieties of crops, introduction of floating bed cropping in flood monsoon, rain water harvesting and encouraging the fish farmers to fresh water shrimp culture to control salinity intrusion.

\section{ACKNOWLEDGEMENT:}

This research was funded by the Deltas, Vulnerability and Climate Change; Migration and Adaptation (DECCMA) Project of the Institute of Water and Flood Management (IWFM), Bangladesh University of Engineering and Technology (BUET) in collaboration with the Internship and Research Program at undergraduate level of the Faculty of Disaster Management (FDM), Patuakhali Science and Technology University (PSTU), Bangladesh.

\section{CONFLICTS OF INTEREST:}

The authors declare that they have no potential conflicts with respect to the research work.

\section{REFERENCES:}

1) Adger, W. N., Huq, S., Brown, K., Conway, D., and Hulme, M. (2003). Adaptation to climate change in the developing world. Progress in development studies, 3(3), 179195.

https://doi.org/10.1191/1464993403ps060oa

2) Ahmed, B., Kelman, I., Fehr, H. K., and Saha, M. (2010). Community resilience to cyclone disasters in coastal Bangladesh. Sustainability, 8(8), 805.

https://doi.org/10.3390/su8080805 
3) Bagchi, R., Miah, M., Islam, S., and Shil, S. (2019). Impacts on Environmental Components of the Proposed Liquefied Petroleum Gas Bottling and Distribution Plant at Dacope Khulna in Bangladesh. J. of Environmental Science and Natural Resources, 11(1-2), 171181.

https://doi.org/10.3329/jesnr.v11i1-2.43384

4) DOE, (2007). Climate Change and Bangladesh. Climate Change Cell, DOE, Comprehensive Disaster Management Program (CDMP), Govt. of Bangladesh, Dhaka.

5) Hossain MM, Majumder KA, Islam $M$, and Nayeem AA. (2019). Study on Ambient Particulate Matter (PM2.5) with Different Mode of Transportation in Dhaka City, Bangladesh. Am. J. Pure Appl. Sci., 1(4), 1219.

https://doi.org/10.34104/ajpab.019.01912190

6) IPCC, (2001). Observed Climate Variability and Change, Third Assessment Report.

7) IPCC, (2007). IPCC Fourth Assessment Report (Working Group 2).
8) IPCC, (2007). Observed Climate Variability and Change, Fourth Assessment Report.

9) Klein, R. J., Nicholls, R. J., and Mimura, N. (1999). Coastal adaptation to climate change: can the IPCC Technical Guidelines be applied? Mitigation and adaptation strategies for global change, 4(3-4), 239-252. https://doi.org/10.1023/A:1009681207419

10) Parry, M. L., Rosenzweig, C., Iglesias, A., Livermore, M., and Fischer, G. (2004). Effects of climate change on global food production under SRES emissions and socio-economic scenarios. Global environmental change, 14(1), 53-67.

https://doi.org/10.1016/j.gloenvcha.2003.10.0 $\underline{08}$

11) Petersen, L., and Shireen, S. (2001). Soil and water salinity in the coastal area of Bangladesh. Bangladesh Soil Resource Development Institute.

12) World Bank, (2002). Bangladesh: Climate Change and Sustainable Development. Bangladesh, Dhaka: Report No 21104.

Citation: Islam MA, Shamsuzzoha M, Rasheduzzaman M, Ghosh RC, and Faisal M. (2019). Assessment on climate change adaptation: a study on coastal area of Khulna district in Bangladesh, Aust. J. Eng. Innov. Technol., 1(6), 14-20. https://doi.org/10.34104/ajeit.019.14020 (C) क्) 